\title{
THE ABILITY OF THE SECOND YEAR STUDENTS OF SMK NEGERI NIBAAF IN WRITING NARRATIVE TEXT
}

\author{
Florida Tay Kabosu ${ }^{1}$, Imanuel Kamlasi ${ }^{2}$ \\ 1,2 English Department, FIP, Timor University, Kefamenanu - NTT - Indonesia \\ ${ }^{1}$ floridakabosu@gmail.com, ${ }^{2}$ ikamlasi@yahoo.com \\ Received: April, 2020; Accepted: July, 2020
}

\begin{abstract}
In this research discussed about how the students the ability writing narrative text of the personal narrative tex in the story. This study aims to answer the problems: have the students mastered to write narrative text. What aspect writing of narrative text is still difficult for them to master to write. To what level is their ability on writing narrative text categorized. In this study, the writer use descriptive qualitative method and the way to get the data, the writer use the writing test. The populations of this study is the second grand students of SMK Negeri Nibaaf in the school year 2019/2020 consisting of class XII TRRH 21 students, but only 10 students were choosen as sample of this study. The result of finding show that the second ability in composing narrative writing with the instrument given is categorized good. It is SMK Negeri Nibaaf have abilities in composing a good narrative writing. It can be seen from the averange score of content is 4,1 vocabulary is 3,6 and language use is 3,8. After analized the data and got the result, the are some conclusion are all the students have mastered narrative writing. on the basic of the averange score good, vocabulary is difficult part of aspect of narrative writing. the students level of mastery is categorized good. It is based on the data that there are 4 of 10 on this level of mastery. Therefore, the second students of SMK Negeri Nibaaf have mastered in writing.
\end{abstract}

Keywords: Ability, writing, narrative

\begin{abstract}
Abstrak
Dalam penelitian ini dibahas tentang bagaimana kemampuan siswa dalam menulis teks naratif dari personal narrative tex dalam cerita tersebut. Penelitian ini bertujuan untuk menjawab permasalahan: apakah siswa sudah menguasai menulis teks naratif. Aspek penulisan teks naratif apa yang masih sulit mereka kuasai. Sampai sejauh mana kemampuan mereka dalam menulis teks naratif dikategorikan. Dalam penelitian ini penulis menggunakan metode deskriptif kualitatif dan cara pengumpulan datanya menggunakan tes tertulis. Populasi dalam penelitian ini adalah siswa kelas XII SMK Negeri Nibaaf tahun pelajaran 2019/2020 yang terdiri dari siswa kelas XII TRRH 21 siswa, namun yang dijadikan sampel penelitian ini hanya 10 siswa. Hasil penelitian menunjukkan bahwa kemampuan kedua dalam mengarang menulis naratif dengan instrumen yang diberikan dikategorikan baik. SMK Negeri Nibaaf memiliki kemampuan dalam menyusun tulisan naratif yang baik. Hal ini terlihat dari rata-rata nilai isi 4,1 kosakata 3,6 dan penggunaan bahasa 3,8. Setelah menganalisis data dan mendapatkan hasil, diperoleh kesimpulan bahwa semua siswa telah menguasai penulisan naratif. Pada dasar nilai rata-rata yang baik, kosakata merupakan bagian yang sulit dari aspek penulisan naratif. tingkat ketuntasan siswa dalam kategori baik. Ini berdasarkan data bahwa ada 4 dari 10 pada tingkat penguasaan ini. Oleh karena itu, siswa kedua SMK Negeri Nibaaf telah menguasai bidang menulis.
\end{abstract}

Kata Kunci: Kemampuan, menulis, naratif

How to Cite: Kabosu, F.T \& Kamlasi, I. (2020). The Ability of the Second year Students of SMK Negeri Nibaaf in Writing Narrative Text. Journal Of Educational Experts (JEE) 3 (2), 60 68. 


\section{INTRODUCTION}

English as an international language is used all over the world. It is used in all international affairs including scientific and technological ones. It is also taught at junior and senior high schools in Indonesia and has been adopted as the first foreign language. As a subject taught, it contains some topics such as listening, speaking, reading, writing and grammar. According to Richards (2002: 136), people use language as a mean of communication. Through using language they can express their ideas or perception among them. They can use it to communicate in oral an written form. In oral form people express their express their ideas orally while in written form they express their ideas in written form, for example: short story and romance.

Writing is important to everyone, because by writing one can express what is on his/her feelings, ideas and emotions. These can be expressed by a word, sentences, phrase or paragraph. In general, people tend to express what they see or feel something. Good writing requires a good knowledge of grammar as well as the art of using the rhetoric of arranging words, phrases, sentences, and paragraphs in such as way as to engage the readers' attention. (Heffeman, 1982: 30) everyone can express his/her feelings, ideas, or emotion in correct English written from if he/she has also mastered English grammar.

Narrative writing is a part of writing subject that tought to the second grade students of SMK Negeri Nibaaf. They learn it at semester I. It aims to enhance their ability to write narrative texts. There some writing text for senior high school, but one of it's narratives are the most interesting one because it tells us about the story and experience that can make the students enjoy the class and feel the story. So it will be quiet easy to them producing the simple text.

In reality, the students of junior high schools still have problems in writing a good text. When the writer observed, she found that their writing mastery was still low. Only some of them could get good score. This might be caused by some factors, such as there is no opportunity for them at schools to write and there is no a special chance for them to read and write at home. In addition, the techniques teachers apply do not motivate them to write.

\section{REVIEW OF RELATED LITERATURE \\ Previous Studies}

This part presents some studies which have previously conducted researches on writing narrative text. Those studies will be reviewed as follows:

Muhammad Hudri and Nadya Ryanti (2015) in their research article entitled ANALYSIS OF STUDENT'S ABILITY IN WRITING NARRATIVE TEXT in Linguistics and ELT Journal at journal.ummat.ac.id found that the ability of the students in writing narrative text was on fair category. Based on the result, 10 students (50\%) got score 56 - 65 (fair), 5 students $(25 \%)$ got score 0 - 45 (very poor), 3 students (15\%) got score 66 - 79 (good), and 2 students (10\%) got score 46 - 55 (poor). Almost of all students are in between 56 - 65 (fair category). Meanwhile, having analyzed the students' ability in each of writing aspects, it can be said that they were in inadequate category because most of them were inadequate in content. In other words, it means that they have very limited of ideas. The problems faced by the students were they made too much grammatical and spelling errors, difficulties in using connectors, and they have limited vocabulary and unable to select the appropriate diction.

Resty Maya Sari, Wisma Yunita and Azwandi (2016) in their research article entitled IMPROVING STUDENTS' ABILITY TO WRITE NARRATIVE TEXT BY USING GRAPHIC ORGANIZER in JOALL (Journal of Applied Linguistics and Literature, Vol 1, No 2) show that using graphic organizer has successfully improved the students' ability in writing narrative text. The improvement was influenced by the used of interesting material chosen and teacher's participation toward the students. 
Ira Puspita (2018) in An Analysis of Students Writing Ability by Composing Narrative Text in ETERNAL (English Teaching Journal, Volume 9, No. 1, February) reported that her study aimed to find out whether any influences composing narrative text to the students writing ability at seventh grade students of STIT Muhammadiyah Tanjung Redeb and to find out the level ability after students composing narrative text. The result showed that shows the pre-test score of the class was 11.617 with standard deviation of 3.065 and the post-test score was 17.617 with standard deviation of 2.146. The post-test scores were higher than the pre-test scores.

T. Thyrhaya Zein, T. Silvana Sinar, Nurlela Nurlela, and Muhammad Yusuf (2019) The Incomplete Linguistic Features and Schematic Structure in EFL University Students' Narrative Texts, published in Journal of Education, Teaching, and Learning (Volume 4 Number 1 March, Pages 203-209) reported that there are 4 different titles of folktales found in the data. From the data, it was commonly found that there is an incomplete part of the schematic structure of narrative text written by students namely complication, evaluation, resolution, and coda. In terms of linguistic features, it is discovered that most of the students have difficulties in differing the tense used covering the use of regular and irregular verbs, and the absence of dialogue. Then, the conclusion can be drawn that the incomplete schematic structure and linguistic features exist in university students' narrative text.

Siti Zahra Pakas, Dewi Kurniawati and Satria Adi Pradana (2019) in their research article entitled "A Comparative Study Between The Use Of Scaffolding Technique And Write Pair Square (Wps) Technique In Increasing Students' Descriptive Text Writing Ability” in English Education: Jurnal Tadris Bahasa Inggris (EE-JTBI) showed that the result of T-test is 3.628 and the result of $\mathrm{T}$-critical is 2.056 , because the $\mathrm{T}$-observed $>\mathrm{T}$-critical. It means that there was a significant different achievement between the students those which one was better after teaching by using WPS and those which one was better after teaching by using Scaffolding toward students' descriptive text writing ability.

Writing is the expression of language in the forms of letter, symbols, or words. At the most basic level, writing is the physical actb of committing words or ideas to some medium, whether it is hieroglyphics linked onto parchment or an email messenger type into a computer. On the other hand, writing is the mental work of inventing ideas, thinking about how to express them, and organizing them into statements and paragraphs that will be clear to a reader.

The defenitions of writing are variously stated by some experts. According to Rivers (1981: 294), writing is conveying information or expression of original ideas in a consecutive way in the new language. In addition, Brown claims that writing is a thinking process. He states that the writing can be planned and given with an unlimited number of revisions before its release. While Elbow (1973) in Brown (2001: 336) adds that writing is a two-step process. The first process is figuring out the meaning and the second process is putting the meaning into language.

\section{Narrative Text}

A narrative text tells a story by representing a sequence of events. Narrative can be dominant pattern in many types of writing formal, such as his tort, biography, autobiography, and journalism as well as less formal such as personal letters and entries in diaries and journals. Narrative text is also an essential part of casual conversation, and it may dominate tell tales. Speech and shaggy dog stories. As well as news the feature stories presented on television. 'Narrative based medicine is about helping people to tell stories that have to be told if all of us are to remain fully human.'

According to Keraf, "Narrative text as a story tells or describes an action in the past time clearly. In addition, Part as to states that narrative text is a type of the text that is purposed to amuse and to deal with actual and various experience in different ways, narrative text also 
deals with problematic events which lead to a crisis or turning points of kind, which in turn find a resolution.

Based on the definition above narrative text is a description of a series of events, either real or imaginary, that is written or told in order to entertain people. This type of text structurally organize the action, thought, and interaction of its characters into pattern of plot. In short, any time you "tell what happened" you are using narrative text.

Although a narrative text may be written for its own sake-that is simply to recount events in most college writing narrative text is used for purpose, and a sequence of events is present to prove a point. The social purpose of this type the text is entertaining because they deal with the unusual and unexpected development of events. It also instruct because they teach readers and listeners that problem patterns of behavior that re generally highly valued. For instance, a narrative essay about first date, your purpose may be to show your readers that dating as a bizarre and often unpleasant ritual. Accordingly, you select and arrange details of the evening that show your readers why dating is bizarre and unpleasant.

Therefore, narrative text is tried to answer the question: what had happened? Narrative text is a story, so it is should have the element that makes the story more interesting to the reader such a conflict and conclusion of the story. Narrative text is a description of series events, either real or imaginary, that is written or told in order to entertain and to amuse the reader.

Based on the above description, it can be concluded that narrative text is storytelling. When we write a narrative essay, we can assentially telling a story, whether we are relating a single story of several related ones, and we can tell it in the first person and third person. Through narration we make statements clear by relating in detail something that has happen. We can develop the story in chronological order.

\section{Elements of Narrative Text}

Narrative writings are divided into two kinds by Joyce and Feez:

a. Non-faction is a kinds of narrative writing that tells the true story. It is often used to recount a person's life story, important historical event, or new stories. This is really a combination of narrative and informational writing, and

b. Faction is a kind of narrative that tells the untrue story. The story made up by the writer such as short story, comics, novels, etc. The main purpose of this fiction is to amuse, or sometimes to teach moral lessons.

Both fiction and nonfiction narration have three elements. They are social function, generic structure and language feature. Three of them will be reviewed as follows:

(1) Social function:

The main purpose of narrative text is to amuse, entertain, and engage the reader in an imaginative experience. A narrative story deals with complications or problematic events which lead to a crisis and in turn finds a resolution.

(2) Generic Structure

The generic structures of narrative text are:

a. Orientation/Exposition: the introduction of what is inside the text. What the text is talk in general. Who involves in the text. When and where is happen,

b. Complication/rising action: A crisis arises. The complication is pushed along by serious of events, during which usually expect some sort of complicating or problem to arise.

It explores the conflict among the participant. Complication is the main element of narrative. Without complication, the text is not narrative. The conflict can be shown as natural, social or psychological conflict, and 
64 Kabosu \& Kamlasi, The Ability of the Second year Students of SMK Negeri Nibaaf in Writing Narrative Text

3. Resolution: The crises are resolved. In this part, the implication may be resolved for better or worse, but it is rarely left completely unresolved although is of course possible in certain types of narrative which leaves us wondering "How did it end?"

\section{Language Feature}

The language features of narrative text are:

a. A narrative text usually uses past tense,

b. The verbs used in narrative are behaviour give example processes and verbal processes. Behavioral processes: do, make, sing, sit, sleep. Verbal processes: say remark insist, ask, and

c. The use of noun pharase, that give example is a noun that followed by adjective, for example: 40 cruel thieves, a beautiful princess and a kinds person.

\section{Research Design}

In this research the writer used descriptive qualitative method. The purpose is to analysis the students' ability in writing narrative text made by the second students of SMK Negeri Nibaaf in the second year of 2019/2020.

\section{Instrument}

In collecting data, the researcher give a writing test to the students. The writer only used one kind, it covered some kinds of picture. In this test, she use writing test consisting of one number, she gave instruction to the students to write a story based on the pictures given the topic is cinderella.

\section{METHOD}

\section{Procedure of Data Collection}

\section{Library Study}

In this study, the writer reads some references an some theories which are really relevant with the problems of this study.

\section{Field Research}

Before writer gives the test to the students at the research site, she did the following steps:

1.) Asked permision from the Head of SMK Negeri Nibaaf in order to conduct the research.

2.) Prepare the test material.

3.) Conducted a meeting with the second grade students of SMK Negeri Nibaaf to inform them about the research.

4.) Administrated a test on the narrative text writing.

5.) Collected the data and identified the result based on the objective of the study.

\section{Technique of Data Analysis}

Dealing with the requirement above, the writer check the data and consider about the standard suggested by Brown (2004) to analyse the data of this research. To measure the student's level of ability, the researcher used some steps as follows:

\section{Codification}

After the writer has done the research, the research use the data to analysis and identifies the result of the student's ability of writing narrative text in the second student's class of SMK Negeri Nibaaf. 


\section{Score}

The writer will give scores to the students' answers, based on scoring rubric for writing Narrative text by Brown (2007). The aspects to be evaluated are content, vocabulary, and grammar.

\section{Categorizing}

The aim of categorizing the data is to facilitate the data of the tabulation of the data. In this study the researcher use the data to know the student's level of mastery and categorize them based on the result of test.

\section{Tabulation}

Based on the classification above the data were expressed in the form of table as the result of the test put in the table to see the student's ability in narrative text.

\section{Analysis}

To assess the student's level of ability, the writer use the standard analytical scoring based on the criteria prepared as follows:

5 : Excellent

4 : Good

3: Averange

$2:$ Weak

1: Poor

\section{RESULT AND DISCUSSIONS}

In this chapter, discussed presentation of finding and discussion of findings. In the data presentation, the writer present the second grade students' score in tables and discussion, she will discuss the findings.

\section{Presentation of Finding}

The are three score components of narrative writing which were scored namely: Content, Vocabulary, and Language Use. Their scores are presented in the following tables :

Table 1. Student's Averange Score

\begin{tabular}{llcc}
\hline NO & Score & Mastery & UnMastery \\
\hline $\mathbf{1}$ & 4.6 & $\checkmark$ & \\
\hline $\mathbf{2}$ & 3.3 & $\checkmark$ & \\
$\mathbf{3}$ & 2.0 & & $\checkmark$ \\
\hline $\mathbf{4}$ & 4.6 & $\checkmark$ & \\
\hline $\mathbf{5}$ & 4,6 & $\checkmark$ & \\
$\mathbf{6}$ & 5.0 & $\checkmark$ & \\
\hline $\mathbf{7}$ & 4.0 & $\checkmark$ & \\
\hline $\mathbf{8}$ & 5.0 & $\checkmark$ & \\
\hline $\mathbf{9}$ & 2.0 & & $\checkmark$ \\
\hline $\mathbf{1 0}$ & 4.3 & $\checkmark$ & \\
\hline Total Score & 3.5 & & \\
\hline Notes & : Right Answer & & \\
$\mathrm{R}$ & : Wrong Answer & & \\
W & : Master & & \\
M & & & \\
UM & Unmaster & &
\end{tabular}


Table 1 showes that students have mastered narrative writing. The data shows that their average score is 3.5. Is indicates that the second grade students of SMK Negeri Nibaaf have mastered Narrative Writing.

Table 2. Student's Level of Ability on Each Component

\begin{tabular}{cccc}
\hline \multirow{2}{*}{ No } & \multicolumn{2}{c}{ Aspect or Component of Narrative writing } \\
\cline { 2 - 4 } $\mathbf{1}$ & Content & Vocabulary & Language use \\
\hline $\mathbf{2}$ & 5 & 4 & 5 \\
\hline $\mathbf{3}$ & 4 & 3 & 3 \\
\hline $\mathbf{4}$ & 5 & 2 & 4 \\
\hline $\mathbf{5}$ & 2 & 4 & 5 \\
\hline $\mathbf{6}$ & 4 & 4 & 4 \\
\hline $\mathbf{7}$ & 5 & 4 & 4 \\
\hline $\mathbf{8}$ & 5 & 3 & 4 \\
\hline $\mathbf{9}$ & 4 & 3 & 2 \\
\hline $\mathbf{1 0}$ & 3 & 5 & 4 \\
\hline T. Sc & 4 & 36 & 33 \\
\hline SAS & 41 & 3.6 & \\
\hline Notes & 4.1 & & \\
C & : Content & \\
V & : Vocabulary & & \\
LU & : Language Use & \\
T. Sc & : Total Score on each Component & \\
SAS & : Students Averange Score on each component & \\
& &
\end{tabular}

Table 2 show that vocabulary is still difficult part of aspects narrative writing. The data show that their averange score is (3.6) lower than language use (3.8) and content (4.1).

Table 3. Classification the Student's Level of Ability

\begin{tabular}{cccc}
\hline NO & Range of Score & Total Number of students & Level of Ability \\
\hline $\mathbf{1}$ & 5 & $2(1,7)$ & Excellent \\
\hline $\mathbf{2}$ & 4 & $4(3,5,6,10)$ & Good \\
\hline $\mathbf{3}$ & 3 & $2(2,8)$ & Averange \\
\hline $\mathbf{4}$ & 2 & $1(9)$ & Weak \\
\hline $\mathbf{5}$ & 1 & $1(4)$ & Poor \\
\hline
\end{tabular}

Table 3 shows that, two students are categorized excellent, four students are categorized good, two students are categorized averange, one students are categorized weak and one students is poor. Show that their level of mastery is categorized good, the data show that there one 4 students on their categorized.

\section{Discussion}

As shown in Table I showes that students have mastered narrative writing. The data shows that their average score is 3.5. Is indicates that the second grade students of SMK Negeri Nibaaf have mastered Narrative Writing.

In Table II show that vocabulary is still difficult part of aspects narrative writing. The data show that their averange score is (3.6) lower than language use (3.8) and content (4.1). While in Table III shows that, two students are categorized excellent, four students are categorized good, two students are categorized averange, one students are categorized weak and one students is poor. Show that their level of mastery is categorized good, the data show that there one 4 students on 
their categorized. It means that to compose a narrative writing, must students have understood the basic concept of narrative writing.

\section{CONCLUSION}

After analysing and describing the finding of the research the writer concludes that:

1) The second year students of SMK Negeri Nibaaf have mastered in narrative writing. It is shown that the avera ge score is 3.5

2) On the basic of the averange score good, vocabulary is difficult part of aspect of narrative writing.

3) The students level of mastery is categorized good. It is based on the data there are 4 of 10 Students on this level of mastery.

\section{REFERENCES}

Arikunto, Suahrsimi. 2006. '’Prosedur Penelitian', Edisi Revisi VI. Jakarta: PT Rineka Cipta. Anderson, Mark, Kathy Anderson, Text Type in English, New York: Maimillan, 1997:1

Brown, H. Douglas. 2001. Teaching by principles: An Interactive approach to Language Reading. New York: Syndicate of the University of Cambridge Press.

Brown, 2004. Language Assessment: Principles and Classroom Practices. White Plains, New York: Pearson Education.

Brookes, S.J. and Grundy, D. 2000. Beginning to Write. Cambridge: Cambridge University Press.

Byrne, D. 1997. Teaching Writing Skills. London: Longman.

Dini Utami Mulyaningsih, 2013. Analysis Of Students' Ability In Writing Narrative Text. English Education Study Program of Indonesia University of Education.

Feez ,S.,\& Joyce,H. (1998:4). Text-based syllabus Design. Sydny: National Center for English Language Teaching and Research, Macquarie University.

Harmer, J. 2004. How to Teach Writing. Harlow: Pearson Education Limited.

Heffeman, 1982: : Quote from Venidora Komi Lake, An Analysis on Narrative Writing of the Second Class Students of SMA Katolik Warta Bakti Kefamenanu In The School Year Of 2012/2013.

Ira Puspita, 2018. In An Analysis of Students Writing Ability by Composing Narrative Text in ETERNAL (English Teaching Journal, Volume 9, No. 1, February)

Lyotard J-F (1984) The Post Modern Condition: a report on knowledge. University of Minnesota Press, Minneapolis.

Launer J (2001) Whatever happened to biology? Reconnecting family therapy with its evolutionary origins. JFam Ther. 23:155-70.

Muhammad Hudri and Nadya Ryanti, 2015. In their research article entitled ANALYSIS OF STUDENT'S ABILITY IN WRITING NARRATIVE TEXT in Linguistics and ELT Journal at journal.ummat.ac.id

María Jesús Fernández, Manuel Lucero and Manuel Montanero, 2016. "Red on black How do teachers assess their students' narrative texts?" in Revista de Educacion 2016 (372): 63 82, January)

Nurhidayah, 2017. An Analysis on the students' Ability in Writing Narrative Text, University of North Medan.

Resty Maya Sari, Wisma Yunita and Azwandi, 2016. In their research article entitled Improving Students' Ability To Write Narrative Text By Using Graphic Organizer in JOALL (Journal of Applied Linguistics and Literature, Vol 1, No 2)

Ruddell, M. R. 2005. Teaching Content Reading and Writing. New York: John Wiley \& Sons. Inc. 
68 Kabosu \& Kamlasi, The Ability of the Second year Students of SMK Negeri Nibaaf in Writing Narrative Text

Roberts G and Holmes J (eds), 1999. Narrative in Psychiatry and Psychotherapy. Oxford University Press, Oxford.

Richards, 2002: Quote from Venidora Komi Lake, An Analysis On Narrative Writing. Of The Second Class Students Of SMA Katolik Warta Bakti Kefamenanu In The School Year Of 2012/2013.

Sternberg, Robert J and Elena L Grigorenko, 2003. The Psychology of Abilities Competencies and Expertise. United States of America: Cambridge University Press

Siti Zahra Pakas, Dewi Kurniawati and Satria Adi Pradana, 2019. In their research article entitled "A Comparative Study between the Use of Scaffolding Technique and Write Pair Square (Wps) Technique in Increasing Students' Descriptive Text Writing Ability" in English Education: Jurnal Tadris Bahasa Inggris (EE-JTBI)

T. Thyrhaya Zein, T. Silvana Sinar, Nurlela Nurlela, and Muhammad Yusuf, 2019. The Incomplete Linguistic Features and Schematic Structure in EFL University Students' Narrative Texts, published in Journal of Education, Teaching, and Learning (Volume 4 Number 1 March, Pages 203-209). 